\title{
Disposal of Pesticide Wastes in Apple Orchards in the South of Brazil and Its Compliance With Current Legislation
}

\author{
Larissa Morello ${ }^{1}$, Simone Vassem de Oliveira ${ }^{1}$, Kelly Scherer de Oliveira ${ }^{1}$, Bruna Fernanda da Silva ${ }^{1}$, \\ Ana Emília Siegloch ${ }^{1} \&$ Lenita Agostinetto ${ }^{1}$ \\ ${ }^{1}$ Postgraduate Program in Environment and Health, University of the Planalto Catarinense, Lages, Santa \\ Catarina, Brazil \\ Correspondence: Lenita Agostinetto, Postgraduate Program in Environment and Health, University of the \\ Planalto Catarinense, Lages, Santa Catarina, Brazil. Tel: 55-493-251-1078 ext. 208. E-mail: \\ prof.leagostinetto@uniplaclages.edu.br
}

Received: March 19, 2019

doi:10.5539/jas.v11n10p140
Accepted: May 17, $2019 \quad$ Online Published: July 15, 2019

URL: https://doi.org/10.5539/jas.v11n10p140

\begin{abstract}
This research aimed to verify how the disposal of pesticide wastes occurs in apple orchards (Malus domestica) in the south of Brazil and to verify its compliance with current legislation. This was a quantitative, descriptive and prospective field study. The research was carried out with 82 farmers from two rural areas belonging to the municipality of São Joaquim, the largest Brazilian apple producer, located in the Serrano Plateau of the State of Santa Catarina, southern Brazil. The farmers were interviewed at home and questioned about the disposal of empty pesticide containers. The results of this research showed that most farmers carry out the proper management of the empty pesticide containers and return them to the collection stations or centers $(85.5 \%)$, the other $8.5 \%$ dispose empty containers inappropriately, keeping them in the open air or burning them. It should be noted that $20.7 \%$ of farmers store these containers in the open air until they are delivered to the collection stations without any protection and exposed to people and animals. In addition, it was observed that individuals without any level of education tend to store empty containers inadequately. Thus, despite the fact that Brazil is a world reference in terms of the proper disposal of empty pesticide containers, there are still cases of non-compliance with the current legislation in relation to these procedures, and there is a need for technical guidance to workers, especially those with lower levels of education, as well as greater rigor of the legislation of supervision by the competent body.
\end{abstract}

Keywords: Malus domestica, pesticide, South America, waste management

\section{Introduction}

In the early 1980s, the debate on the effects of uncontrolled use of pesticides on health and agricultural development grew worldwide. As a result, international, national and governmental organizations have approved and implemented laws and rules to regulate the use of pesticides. The International Code of Conduct, developed by the United Nations (UN), was one of these legal provisions dealing with the Distribution and Use of Pesticides in 1985 (Food and Agriculture Organization of the United Nations [FAO], 2002). In 2002, FAO adopted the Code of Conformity, incorporating concerns and experiences seeking to rationalize the use of pesticides in the world and reduce risks to health and to the environment (FAO, 2002).

In Brazil, the Pesticides Law (Law No. 7,802/1989) was created in 1989 to limit the use of pesticides in agriculture. However, despite the progress made with the implementation of the legislation, there was lack of standardization, focused mainly on the management of empty pesticide containers, their transportation and storage. On June 6, 2000, Law No. 7,082/1989 was updated by Law No. 9,974 through Decree 4.704/02, which regulates the transportation, storage and disposal of empty pesticide containers, making the farmer, the reseller and the manufacturer responsible for the final destination of empty containers and their wastes. Thus, the legislation presents a division of responsibility among users, sellers and manufacturers, with the Public Authority being responsible for guiding and supervising pesticides (Cirne, 2006). In 2010, with the promulgation of the National Solid Waste Policy (PNRS, Law No. 12,305/2010), the shared responsibility for waste disposal was created, making all users of the chain responsible for carrying out Reverse Logistics, including the pesticides in this system (Brasil Law No. 12,305/2010). 
In addition, in 2001, the National Institute for Processing Empty Packages (INPEV) was created in Brazil, which established the Brazilian program of reverse logistics for empty containers of pesticides, known as Campo Limpo System, which helped Brazil to become a world reference in environmentally correct disposal of empty pesticide containers, with an annual average of $94 \%$ of primary plastic containers correctly marketed and destined, followed by France and Canada with 77\% and 73\%, respectively (INPEV, 2016).

However, despite the achievements of the Brazilian legislation on the disposal of pesticide wastes, there are still difficulties in complying with legislation in rural areas (De Souza, 2018; Terto \& Andrade, 2017). While some European countries, concerned about the negative effects of pesticides on the environment and on the health of the population, have created strategies to avoid or restrict the use of these chemicals, Brazil regresses on this point.

Sweden, e.g., was one of the first countries to create a simple tax regime based on an environmental tax calculated by the $\mathrm{kg}$ of the active ingredient sold, being $€ 3.25$ per $\mathrm{kg}$ of active ingredient; Norway, on the other hand, stands out because it uses a tax system whose level of taxation is determined by the area of property versus the quantity of product used according to its toxicity, with the value of taxation varying from $€=2.6$ per hectare to $€=20.8$ per hectare. Belgium also charges taxes on the sale of certain actives ingredients of pesticides, according to their toxicity, whose tax increases as the toxicological class increases (Skevas, Lansink, \& Stefanou, 2013).

On the other hand, Brazil has regressed in the legal aspect, making flexible, among other things, the registration and commercialization of pesticides in the country, since it is currently in the Brazilian Senate a bill that seeks to make Law 7802/89 less rigid, whose bill has already been approved in one of the stages of the process. Thus, it is clear that when comparing Brazil with other European countries, there is still much to advance in the legal aspects on pesticides (Bombardi, 2017).

As if this were not enough, another aspect that makes the sale of these chemicals viable in Brazil is the granting of a $60 \%$ reduction in ICMS (Tax on the Circulation of Goods and Services), total exemption from PIS/COFINS (Social Security contributions) and of IPI (Tax on Industrialized Products). Thus, what remains of the tax on pesticides accounts for only $22 \%$ of the total value of the product, unlike other products which are also considered dangerous, whose tax revenue often exceeds $30 \%$, precisely to restrict the circulation of these products in the country (Friedrich et al., 2018).

These tax benefits and the relaxation of the legislation are justified by the government through the argument that pesticides are essential for the country's agricultural production and because they are commodities, an important factor to leverage the Brazilian Gross Domestic Product. However, this discourse constitutes a stimulus tool to commercialize actives ingredients that can no longer be freely produced or consumed in other countries due to their toxicity and the danger they pose to humans and to the environment (De Souza, 2018; Friedrich et al., 2018).

This becomes even more serious considering that Brazil is one of the world's largest agricultural producers, whose chemical control is the most used mechanism in the management of agricultural crops (Mello \& Scapini, 2016; Mecabô, 2018) and since 2008 it has become the world's largest consumer of pesticides, including actives ingredients already banned from the European market (Frazier, 2007).

In Brazil, the southern region of the country, which includes the states of Santa Catarina, Rio Grande do Sul and Paraná, is prominent in the production of apples (Malus domestica Borkh) due to the climatic conditions of this region that favors the development of the crop, besides representing a large part of the economy of these States due to the creation of jobs and income (Maluche-Barreta, Klauberg Filho, Amarante, Genicelli, \& Almeida, 2007). The State of Santa Catarina ranks first in the national ranking of apple production with an annual average production of 525,953 tons (Instituto Brasileiro de Geografia e Estatística [IBGE], 2016).

Nevertheless, the system of apple cultivation in the country annually consumes significant amounts of pesticides, which allows the occurrence of risks, often irreversible, to human health and to the environment (Eskenazi, Bradman, \& Castorina, 1999; Oliveira-Silva, Alves, \& Meyer, 2001; Moreira, Jacob, \& Peres, 2002; M. M. Veiga, Silva, \& L. B. E. Veiga, 2006; Marques, Vieira, \& Junior, 2015; Santos \& Machado, 2015; Carvalho, 2017). It is also noted that farmers in many developing countries, such as Brazil, suffer significant damage to health and to the environment through excessive pesticide application, especially in cases in which there are no regulatory laws or lack of technical guidance to manage the wastes of these substances (Dasgupta, Meisner, Wheeler, \& Jin, 2002). 
In view of this panorama, this research aimed to verify how the disposal of pesticide wastes occurs in apple orchards in the south of Brazil and to verify its compliance with current legislation.

\section{Method}

\subsection{Type and Place of Study}

This was a quantitative, descriptive and prospective field study. The study was carried out in two rural localities belonging to the municipality of São Joaquim, the largest Brazilian apple producer, located in the Serrano Plateau of the State of Santa Catarina, southern Brazil. The municipality has an altitude of 1,350 meters and a rugged relief consisting of basalt and plateau, humid temperate climate, according to Köppen classification, annual average temperature of $13{ }^{\circ} \mathrm{C}$, and severe winters with frost occurrence, edaphic and climatic characteristics that favors the cultivation of temperate fruits such as apples (Secretaria do Estado de Desenvolvimento [SDR], 2003). In addition, the vegetation prevalent in the region are forest remnants of the Atlantic Forest Biome with predominance of Araucaria angustifolia forests, a species with a current threatened conservation status. In the region there are also springs of several important rivers of the State, whose waters serve as supply to the local population (Secretaria do Estado de Desenvolvimento [SDR], 2003).

\subsection{Study Participants}

The first area selected for the study is characterized by the apple cultivation in small farms with the use of family labor, whose area of apple cultivation is 580.60 hectares, distributed in approximately 100 orchards. The choice for this region was due to the topographic characteristic of the region that is presented as a valley, where the orchards are arranged at the highest part of the property and the farmers reside in the lowlands, within the orchard, which favors the risk of pesticide poisoning. In addition, the cultivated areas are often situated on the slopes of rivers, which may contaminate the water and the water table through applications or improper disposal of pesticide waste. It is also worth noting that in valley regions, the solid particles released into the environment hardly dissipate and remain accumulated in the region, and that during the period of greatest demand of pesticide applications in the crop (September to January) these particles remain as mist on the site and may cause problems for farmers and for the environment.

The second studied area is composed of an apple cultivation area of 384.5 ha, totaling approximately 63 orchards and is characterized by the predominance of hired labor and service providers, also the owner of the orchard assumes the role of business manager.

Thus, we expected to carry out the survey with the 163 farmers; however, the sample of this study was composed of 82 farmers, due to the exclusion and inclusion criteria of the research that established that the interviewees should belong to the delimited localities and regardless of the size of the cultivated area. They should use the conventional or integrated system of apple production and they should agree to participate in the study of their own free will by signing the Informed Consent Term (ICT). In addition, those individuals who after three home visits were not found by the researchers were disregarded in this study.

\subsection{Data Collect and Analysis}

The data collection was performed through an interview with the farmers using a structured questionnaire with some open questions. The questionnaire addressed issues related to the socio-demographic data of the farmers and their properties; types of pesticides used; destination of empty containers; triple wash and rendering the containers useless. The knowledgement about the process of returning and storage of empty pesticide containers, disposal of leftover pesticides and of the water from the triple wash were asked. In addition, field observation was carried out at each farm, investigating how the empty pesticide containers were disposed and stored in the rural properties. The data collection was carried out from August to December 2017 in the residence of each farmer, and each interview lasted approximately 30 minutes.

The data obtained from the interviews were organized in Excel spreadsheets and submitted to descriptive statistical procedures (mean, percentage and standard deviation). The results were presented in charts and tables bringing resources for discussion and conclusions through quantitative descriptive analysis. Furthermore, the pesticide waste disposal data were associated with the socio-demographic data on educational level, gender and age of the participants, by means of the chi-squared test through the Statistical Package for the Social software-SPSS, version 20. 


\section{Results and Discussion}

\subsection{Characterization of Properties and Farmers}

In this study, data were collected from 82 farmers who grow apples, $85.4 \%$ of which are male and $14.6 \%$ are female. The mean age of participants was $46( \pm 14)$ years old. The largest number of workers was in the age group of 40 to 49 years old. However, 16 farmers were over 60 years old and only one individual was under the age of 20, evidencing the aging of the farmer and the presence of few young people in the field to continue the work, which could jeopardize the future of Brazilian family farming. According to Bedor (2009), it is not common to find a large number of young people in the agricultural sector, since the living conditions of most workers are compromised by low income, temporary contracts and they often have no guarantee of a promising future which makes young people look for new job and income opportunities in other areas.

Concerning the educational level, $40 \%$ of the farmers did not complete elementary school, $22 \%$ completed high school, $4 \%$ have technical education and only $2 \%$ completed higher education. Low educational level may negatively influence the management of family property, regarding the use of new scientific techniques, as well as the perception of the farmer about the importance of the correct use of pesticides and the sustainability of his property (Viana, Queiroz, \& Ribeiro, 2017). The low level of education of the farmers associated to the absence of adequate technical guidance during the production process may imply the difficulty of reading and interpreting pesticide labels since most of the information is technical (Ribeiro, de Moura Alves, \& de Moura Lustosa et al., 2017). On the other hand, more educated farmers may handle pesticides with greater care, avoiding their exposure to chemicals (Dasgupta et al., 2002).

Regarding the type of relationship of the interviewee with the property, the majority (88\%) owns the orchard and uses family labor (94\%). It is worth noting that family farming in Brazil represents $84 \%$ of Brazilian rural establishments,-and is composed of approximately 4.4 million families responsible for producing more than $50 \%$ of the food in the Brazilian cesta básica (set of products used by a family during the period of one month) (IBGE, 2017).

Employee hiring varied between 0 and 20 people $(\mu=3 \pm 4)$ and occurs especially at the end of the crop of apples due to the harvest. In this period, there is a greater demand for labor since it is a short period and fruits should be harvested as soon as they ripen to avoid post-harvest losses (De Lima, Grützmacher, \& Krüger, 2009).

The studied properties presented a mean of 38.1 ha ( $\mathrm{SD} \pm 73.8 \mathrm{ha}$ ), whose cultivated area ranged from 1 to 27 ha $(\mu=5 \pm 4)$, with a mean production of 52 tons/ha of apple ( $\mathrm{SD} \pm 21$ tonnes/ha). The production of apples in the region may be considered high, since it surpasses the mean productivity of apples in Brazil, which varies from 15 to 30 tons/ha in orchards conducted with modern and sophisticated techniques (Serviço Brasileiro de Apoio às Micro e Pequenas Empresas [SEBRAE], 2018). Of the properties visited, 95\% receive technical assistance and the system of cultivation is predominantly conventional (81\%); however, there is a small portion under the integrated system of cultivation (19\%). The integrated system is the joint use of techniques and practices, with emphasis on the reduction of pesticides, prioritizing biological, cultural and physical methods to control pests and diseases, reducing the risks of environmental contamination and preserving human health (Farias et al., 2003). Unfortunately, in this research, few farmers have reported using this cultivation practice.

\subsection{Use of Pesticides by Farmers}

The farmers in the region make use of 29 actives ingredients of pesticides distributed in 38 formulated products. Of the used formulated products, $71 \%$ correspond to the class of fungicides, $18.4 \%$ to the class of insecticides and $5.3 \%$ to the class of herbicides and acaricides (Appendix A).

The pesticides Mancozeb (Dithane ${ }^{\circledR}$ ), fenitrothion (Sumithion ${ }^{\circledR}$ ), difenoconazole (Score $®$ ) and Captan $\left(\right.$ Captan $\left.{ }^{\circledR}\right)$ were the pesticides most used by the interviewed farmers $78.05 \%, 60.97 \%, 57.32 \%$ and $52.44 \%$ of the interviewees make use of these products, respectively (Complementary Material). The study conducted by Da Rosa et al. (2018) with farmers who cultivate apples in the municipality of São Joaquim, Santa Catarina, also detected that the fungicides Dithane ${ }^{\circledR}$ (Mancozeb) and Captan ${ }^{\circledR}$ (Captan) were among the most used during the flowering period of the apple for the preventive control of apple scab (Venturia inaequalis). These pesticides correspond to toxicological classes between average and extremely toxic, and to environmental class very dangerous to the environment. This makes these products dangerous if handled and/or disposed in the environment without any care (Frazier, 2007).

The Dithane ${ }^{\circledR}$ fungicide, although banned in several countries, is still widely used in Brazil and in several agricultural crops (Vinha, de Oliveira Pinto, \& Pinto, 2011). According to the same authors, this product may cause serious impacts to health, such as cancer, mutation and malformations in the fetus. A number of studies 
have shown that many of the pesticides used in agriculture have contributed to potential risks of environmental and human contamination (Eskenazi et al., 1999; Oliveira-Silva et al., 2001; Moreira et al., 2002; Veiga et al., 2006; Marques et al., 2015; Santos \& Machado, 2015; Carvalho, 2017).

\subsection{Management of Empty Pesticide Containers}

Triple wash is the cleaning of the empty containers with water and shaking them three times, whose leftovers are dumped in the spray tank or stored in a specific reservoir for this purpose (Gerassi, 2010). This procedure is carried out because the improper destination and washing of pesticide containers cause several problems to the environment, such as soil, water sources and air contamination, and simultaneously problems to human health (Eskenazi et al., 1999; Moreira et al., 2002; Veiga et al., 2006; Marques et al., 2015; Santos \& Machado, 2015; Carvalho, 2017).

Most of the interviewees (87.8\%) are aware of the obligation of triple wash, $90.2 \%$ carry out this procedure, $76.8 \%$ render the empty containers useless, and $86.6 \%$ do it at a distance of more than 30 meters from their residence, and usually in a specific place for this purpose, in the orchard itself ( $64.8 \%$ of respondents). However, $9.8 \%$ of the farmers do not carry out the triple wash and $6.1 \%$ of the interviewees never render empty containers useless and $11 \%$ do not always render these containers useless.

According to Brazilian Laws 7,082/1989 and 9,974/2000, users who purchase pesticides have the obligation to return the empty containers to a collection station or to the seller, who must return them to the manufacturer, following the reverse logistics process, as defined by the National Solid Waste Policy (Law no. 7,802/1989). According to the INPEV, during the return of the containers, in order to be accepted at the collection stations, it is necessary that the bottles are clean, rendered useless and with their caps stored separately (INPEV, 2016). In this case, the farmer must carry out the triple wash, in addition to rendering them useless by perforating the bottom of the container to return.

In this study, $20.7 \%$ of the interviewees stored the empty pesticide containers in a shed along with other agricultural and domestic products, and another $20.7 \%$ stored them in the open air without any protection and exposed to people and domestic animals, and only after this they return them. In Ardabil province, Iran, a study with 185 apple producers found that $32.8 \%$ of the respondents disposed and/or stored the empty pesticide bottles in the orchards themselves, while $30.2 \%$ reported that they bury empty containers (Bagheri et al., 2018). The storage location of empty containers is important because when stored unproperly, pesticides pose little risk to human health and to the environment (Huici, Skovgaard, Condarco, Jørs, \& Jensen, 2017). In a survey carried out in two municipalities of Santa Cruz, Bolivia, with 361 farmers, the data found show that in the visited properties the empty pesticide containers are treated as any other bottle, without any utility and without danger, therefore, they are stored and disposed in inappropriate places without any care (Huici et al., 2017). Thus, it is well-known that the problems related to the neglect of the storage and disposal of empty pesticide containers is not only a regional or national problem, however, it is a global problem, especially in underdeveloped or developing countries.

Regarding the disposal of empty containers, the majority (85.5\%) of the interviewees delivered the pesticides at the place of purchase. Nonetheless, $7.3 \%$ of farmers keep the containers stored in the open air without returning them, a worrying fact, for the possibility of human and environmental contamination is enormous. Since, these containers are contaminated by toxic products and their constituent material is not biodegradable. In addition, $1.2 \%$ of the interviewees still practice a technique that has been irregular for a long time which is the burning of empty containers (Figure 1). Thus releasing into the environment a series of toxic gases, such as dioxins, dibenzofurans, polycyclic aromatic hydrocarbons, furans and the suspended solids (PM10 and PM2.5) (Marnasidis, Stamatelatou, Verikouki, \& Kazantzis, 2018). It should be noted that PM2.5 currently represents one of the main air pollutants at the global level and is classified as the fifth mortality risk factor in the world, accounting for $7.6 \%$ of total global deaths in 2015 (Cohen et al., 2018). 


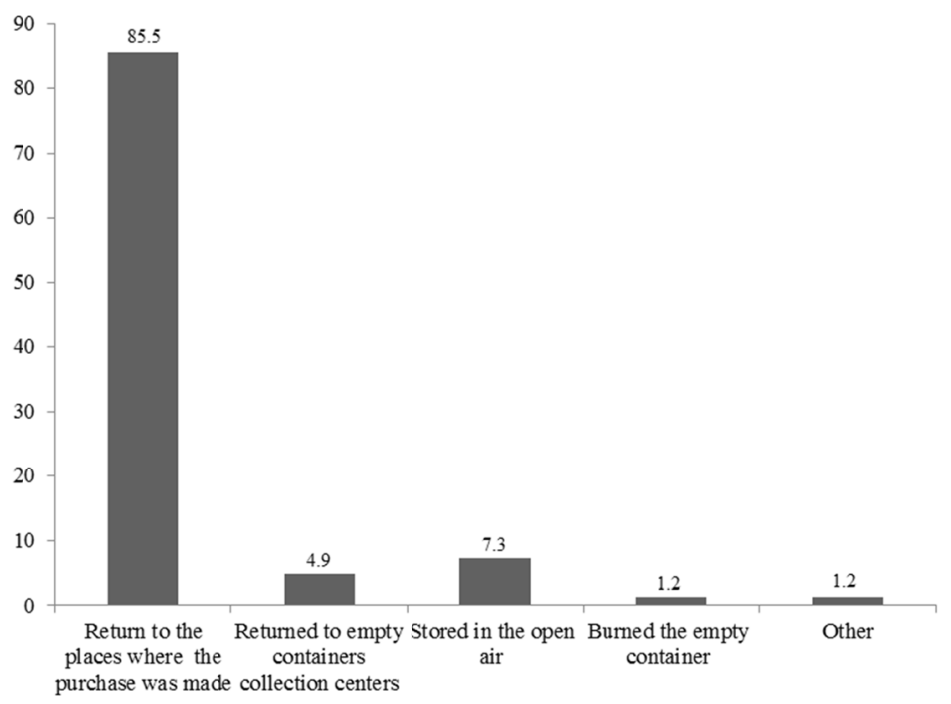

Figure 1. Destination of empty pesticide containers (\%) by farmers who grow apples in the municipality of São Joaquim, SC $(n=82)$

This research has demonstrated that some of the practices adopted for the management of empty pesticide containers are inadequate under current Brazilian legislation. A similar survey carried out with farmers in Bahia, northeastern Brazil, showed that $50 \%$ of those interviewed still burn empty pesticide containers; $37.5 \%$ dispose them without any care with the environment; $7.5 \%$ reuse them as a water container for domestic animals; $5 \%$ bury them; and none of the respondents returns them to the seller (De Souza, Faria, \& Pereira, 2017). The inadequate disposal of empty containers may lead to the leaching of the pesticide leftovers present in the containers, whose residues are responsible for causing soil, groundwater and surface water contamination (Da Costa Leite, \& Torres, 2008).

It is worth emphasizing that because it is a hazardous waste, Brazilian legislation has made compulsory the return of empty pesticide containers, in this case farmers, manufacturers, importers, distributors and pesticide sellers have an obligation to promote the reverse logistics system of these products (Terto \& Andrade, 2017). According to the latest INPEV sustainability report (INPEV, 2016), Brazil is a world reference in the reverse logistics of empty pesticide containers and $94 \%$ of the sold primary plastic containers have a correct environmental destination. However, in spite of these data, this research shows that there are farmers who still do not follow the norms of the legislation and that there are still improvements to be made in the Brazilian countryside in order that the reverse logistics system continues to work and that Brazil continues to lead this ranking.

\subsection{Management of Leftovers of Pesticide Residues, Expired Products and Water from the Triple Wash}

Regarding leftover of pesticide residues in the sprayer, most (58.5\%) of the respondents answered that there is no product left, $28 \%$ of the interviewees keep them in the turbine of the sprayer tractor and use them for the next crop application (Figure 2) with the intention of not wasting pesticide because it is a product of high cost. A small part of the interviewees (3.7\%) mix the leftovers of the residues with other products and reapply them (Figure 2). This practice may cause environmental problems, since the mixed products may become even more toxic, since the effect of the interaction between two actives principles ingredients is often unknown (De Castro, 2009). In addition, it was observed that $2.4 \%$ of the interviewees dispose leftovers of pesticide residues in the soil without any care and concern for the environment (Figure 2). 


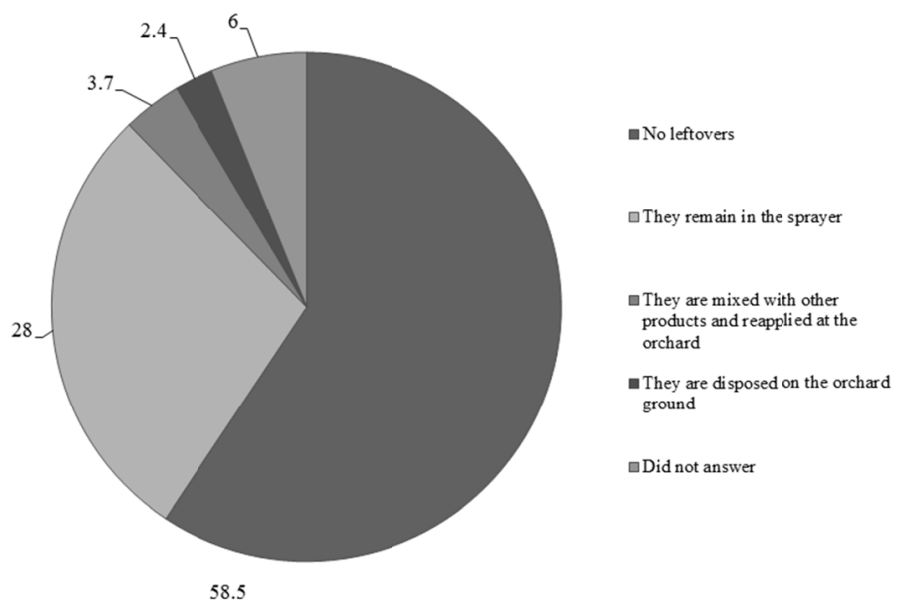

Figure 2. Management of the leftovers of pesticide residues of the sprayer (\%) after application to the orchard by farmers in the municipality of São Joaquim, SC $(n=82)$

The absence of leftovers after the application of pesticides may be due to the reapplication of the product and not necessarily by the correct calculation of the quantity to be applied. In this case, farmers may be applying more than the amount needed for the crop. Regarding the reuse of the residues, it is known that they can not be stored after preparation, since the effects of the chemical interactions and the by-products generated in these mixtures are unknown (Chaves Preza \& Da Silva Augusto, 2012). The risks due to environmental disorders are difficult to prevent due to the complexity and variability of the ecosystems and their organisms, since the same situation may lead to several responses depending on several intercurrent environmental conditions (Peres \& Moreira, 2007).

Concerning the leftovers of pesticide residues, most farmers (72\%) responded that they keep them in their own container and store them for the next application, $19.5 \%$ stated that there is no product left in the bottles because they use everything in a single application (Figure 3). Nevertheless, $5 \%$ use the whole product even if it exceeds the dose recommended by the manufacturer (Figure 3). Similarly, a study carried out with Vietnamese farmers on the use of pesticides showed that leftovers of pesticide residues were improperly disposed, and the most common method was disposing them in the crop until the sprayer tank was completely emptied (Nguyen, Havukainen, \& Hannaway, 2017). According to these authors, incorrect methods of disposal imply potential risks to flora and fauna, increasing the probability of raising levels of residues in produced food, reducing natural enemies, impacts on the applicators' health, environmental contamination and moreover raising the cost of production (Nguyen, Havukainen, \& Hannaway, 2017).

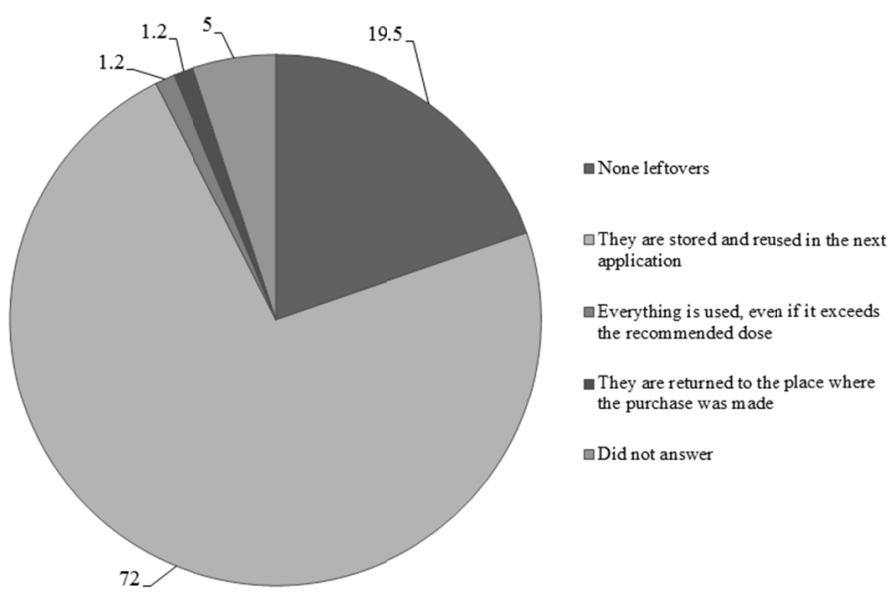

Figure 3. Management of leftovers of the pesticide bottles (\%) by farmers who grow apples in the municipality of São Joaquim, SC ( $\mathrm{n}=82)$ 
In relation to expired pesticides, $59.8 \%$ of the interviewees reported that there is not enough time for the pesticides to expire since they are high cost products and they only purchase the quantity that will be used (Figure 4). Another 22\% reported that they returned them to the seller, however, a small portion (4.9\%) responded that they use the pesticides that had expired (Figure 4).

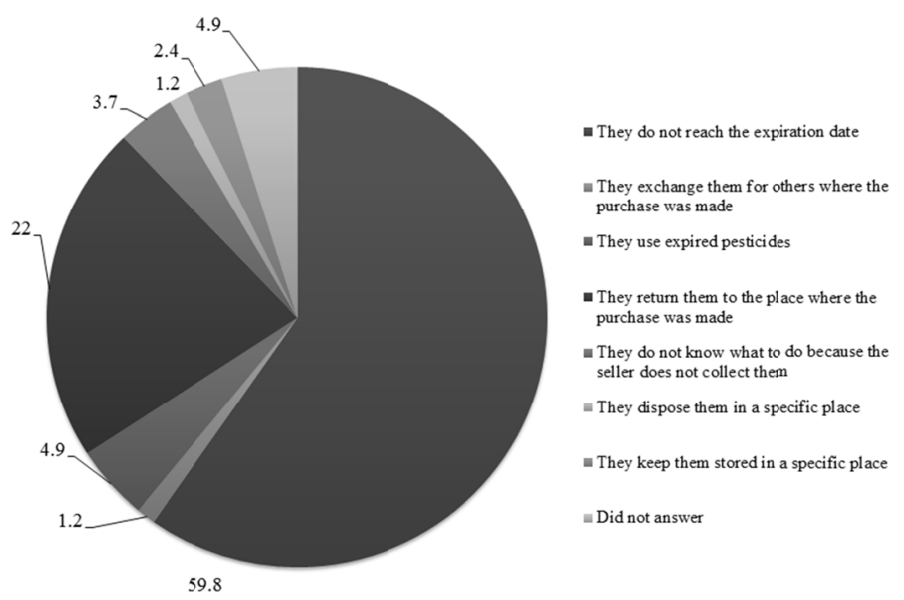

Figure 4. Management of the leftovers of expired pesticides (\%) by farmers who grow apples in the municipality of São Joaquim, SC $(\mathrm{n}=82)$

Similar data were found in a study on the perception of producers regarding the application of pesticides in the production of fresh peach in Rio Grande do Sul, who claimed that they only buy what is necessary and, therefore, there are no expired products on their properties (Pegoraro et al., 2016). In addition, the same study reports that some farmers stated that expired products are stored together with the empty containers in the shed where the pesticides are and only one producer responded that he applies expired pesticides to the crop.

There may be many problems associated with the use of expired pesticides, such as contamination of the environment and the occurrence of serious poisoning by those who handle and apply these products, since many farmers believe that because the product is expired, when using a higher dosage the pesticide will not cause health damage and will maintain its effectiveness (Luna, Sales, \& Silva, 2011).

According to the Brazilian legislation on pesticides, the leftovers from the wash of the container of these products must be added to the sprayer tank and reapplied in the crop, ensuring the full utilization of the contents of the container and reducing the risks of human, animal and environmental contamination (Gerassi, 2010).

In the present study, $69.5 \%$ of the farmers claimed to leave leftover water from the triple wash in the sprayer and use it in the next application and 8.5\% dispose it in a specific well where the sprayer supply is performed (Figure 5). However, $12.2 \%$ of the interviewees dispose these leftovers in any way at the orchard and $1.2 \%$ use the water from the triple wash to clean the tractor (Figure 5). 


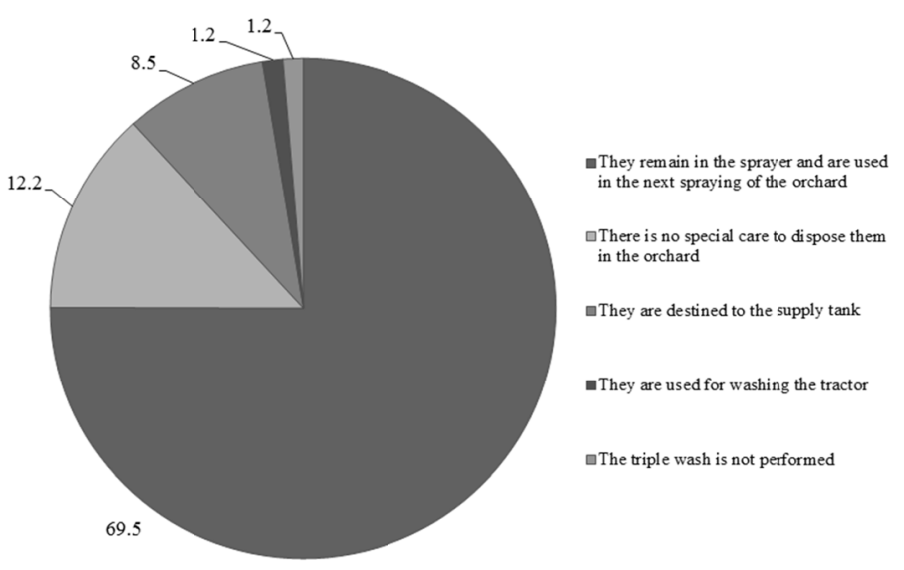

Figure 5. Management of water leftovers from the triple wash (\%) by farmers who grow apples in the municipality of São Joaquim, SC $(n=82)$

Similarly, Marques, Vieira, and Junior (2016), in their research on the reverse logistics of empty pesticide containers with rural producers in Tupã, SP, found that most of the interviewees return the water from the triple wash to the tank or pump, to make the most of the product. Thus, it is observed that the majority of Brazilian rural producers have properly performed the process, because according to INPEV recommendations, this water must be thrown into the sprayer tank (INPEV, 2016).

\subsection{Association of Socio-demographic Data with Pesticide Management}

The socio-demographic variables related to educational level, gender and age were crossed with data related to waste disposal and pesticide containers.

The association of level of education with waste disposal and pesticide containers data showed statistical significance $(\mathrm{p}<0.005)$ for some of the analyzed variables. Tables 1 and 2 describe the associations that showed significance between the variables educational level and management of pesticides. Crossing the variables gender and age with the disposal of pesticides did not present any significant association by the chi-squared test at $5 \%$ significance.

The level of education of the farmers had a significant association with the place where they store empty pesticide containers $(\mathrm{p}<0.018)$ (Table 1$)$. In this case, it is observed that the two farmers who reported being illiterate leave the containers of pesticides in the open air, however, those with higher education properly dispose the empty containers (Table 1).

It is worth noting that according to Regulation 9843, it is advised that the storage of containers must occur in a minimum distance of 30 meters from water sources, residences and animal facilities (Regulation No. 9843/2004). 
Table 1. Association between the educational level of farmers who grow apples in the municipality of São Joaquim, SC, with the storage location of empty pesticide containers

\begin{tabular}{|c|c|c|c|c|c|c|c|c|c|c|c|}
\hline \multirow{3}{*}{ Level of Education } & \multicolumn{11}{|c|}{ Place of storage of empty pesticide containers $(n=82)$} \\
\hline & \multicolumn{2}{|c|}{$\begin{array}{l}\text { Shed exclusive for } \\
\text { pesticide storage }\end{array}$} & \multicolumn{2}{|c|}{$\begin{array}{c}\text { Shed with other } \\
\text { products of agricultural } \\
\text { and domestic use }\end{array}$} & \multicolumn{2}{|c|}{ Orchard } & \multicolumn{2}{|c|}{ Open air } & \multicolumn{2}{|c|}{ Other } & \multirow[t]{2}{*}{$p$} \\
\hline & $\mathrm{n}$ & $\%$ & $\mathrm{n}$ & $\%$ & $\mathrm{n}$ & $\%$ & $\mathrm{n}$ & $\%$ & $\mathrm{n}$ & $\%$ & \\
\hline Illiterate & 0 & 0.0 & 0 & 0.0 & 1 & 50.0 & 2 & 100.0 & 0 & 0.0 & \multirow{8}{*}{0.018} \\
\hline Incomplete elementary school & 17 & 51.5 & 9 & 27.3 & 1 & 3.0 & 6 & 18.2 & 0 & 0.0 & \\
\hline Complete elementary school & 7 & 53.8 & 4 & 30.8 & 0 & 0.0 & 2 & 15.4 & 0 & 0.0 & \\
\hline Incomplete high school & 5 & 50.0 & 1 & 10.0 & 2 & 20.0 & 2 & 20.0 & 0 & 0.0 & \\
\hline Complete high school & 10 & 55.6 & 3 & 16.7 & 4 & 22.0 & 1 & 5.6 & 0 & 0.0 & \\
\hline Incomplete higher education & 1 & 100.0 & 0 & 0.0 & 0 & 0.0 & 0 & 0.0 & 0 & 0.0 & \\
\hline Complete higher education & 2 & 100.0 & 0 & 0.0 & 0 & 0.0 & 0 & 0.0 & 0 & 0.0 & \\
\hline Technical education & 1 & 33.3 & 0 & 0.0 & 0 & 0.0 & 1 & 33.3 & 1 & 33.3 & \\
\hline
\end{tabular}

In the study conducted by Chaves Preza and Da Silva Augusto (2012) on the vulnerability of rural workers regarding the use of pesticides in the production of vegetables in the northeastern region of Brazil, the proportion of illiterates was $31 \%$ and all of them disposed of and stored empty containers inadequately in the field. The high proportion of poorly educated farmers, in addition to other factors such as a lack of specific technical guidance and having the seller as a guide to the use of pesticides, are worrying factors, since these factors may contribute to the increase of cases of intoxication of farmers by pesticides (Carvalho, 2017).

The level of education of the farmers also showed a significant association with the distance between the washing place of the empty pesticide containers and their residence $(p<0.001)$ (Table 2). In this case, it is observed that the only farmer who has incomplete higher education reported that he does the washing of these containers at a distance of less than 30 meters from his residence (Table 2), showing that even with a high level of education, the management of pesticides may be inadequate, possibly due to the farmer's neglect to recognize the potential risks associated with improperly performing such activity.

Table 2. Association between the educational level of farmers who grow apples in the municipality of São Joaquim, SC, with the distance between their residence and the place where they carry out the washing of the empty pesticide containers used in the property

\begin{tabular}{|c|c|c|c|c|c|}
\hline \multirow{3}{*}{ Level of Education } & \multicolumn{5}{|c|}{ Distance from the place where the empty containers are washed to the residence $(\mathrm{n}=82)$} \\
\hline & \multicolumn{2}{|c|}{ Up to 30 meters } & \multicolumn{2}{|c|}{ Above 30 meters } & \multirow{2}{*}{$p$} \\
\hline & $\mathrm{n}$ & $\%$ & $\mathrm{n}$ & $\%$ & \\
\hline Illiterate & 0 & 0.0 & 2 & 100.0 & 0.001 \\
\hline Incomplete elementary school & 1 & 3.4 & 28 & 96.6 & \\
\hline Complete elementary school & 0 & 0.0 & 11 & 100.0 & \\
\hline Incomplete high school & 0 & 0.0 & 9 & 100.0 & \\
\hline Complete high school & 1 & 5.9 & 16 & 94.1 & \\
\hline Incomplete higher education & 1 & 100.0 & 0 & 0.0 & \\
\hline Complete higher education & 0 & 0.0 & 2 & 100.0 & \\
\hline Technical education & 0 & 0.0 & 3 & 100.0 & \\
\hline
\end{tabular}

\section{Conclusion}

The results of this research show that the disposal of pesticide wastes in apple orchards in the southern region of Brazil has been adequately performed. However, it is noteworthy that in this region, part of the storage of empty pesticide containers still occurs in the open air, without any protection, and exposed to people and animals and in some cases, in an inappropriate destination. It is also possible to observe that part of the farmers do not carried out the triple wash and do not render the empty pesticide containers useless. 
The lack of knowledge of the farmers on the management of pesticide wastes is serious, especially when farmers do not have any level of education because they tend to carry out the storage of empty containers incorrectly and in disagreement with the current legislation, making it a risk factor for your health and for the environment.

\section{Acknowledgements}

To Conselho Nacional de Desenvolvimento Científico e Tecnológico (CNPq) through the search call Nexus II, 441396/2017-8 that partially gave financial support to the project research.

\section{References}

Bagheri, A., Emami, N., Allahyari, M. S., \& Damalas, C. A. (2018). Pesticide handling practices, health risks, and determinants of safety behavior among Iranian apple farmerspp. Human and Ecological Risk Assessment: An International Journal, 24(8), 1-15. https://doi.org/10.1080/10807039.2018.1443265

Bedor, C. N. G., Ramos, L. O., \& Pereira, P. J. (2009). Vulnerabilidades e situações de riscos relacionados ao uso de agrotóxicos na fruticultura irrigada. Revista Brasileira de Epidemiologia, 12(1), 39-49. https://doi.org/10.1590/S1415-790X2009000100005

Bombardi, L. (2017). Geografia do uso de agrotóxicos no Brasil e conexões com a União Européia. FFLCH-USP: São Paulo. Retrieved from https:/drive.google.com/file/d/1ci7nzJPm_J6XYNkdv_rt-nbF $\mathrm{mOETH} 80 \mathrm{G} / \mathrm{view}$

Brasil, Law No. 7,802/1989. Lei n. 7.802 de 11 de julho de 1989. Retrieved from http://www.planalto.gov.br/ ccivil_03/LEIS/L7802.htm

Brasil, Law No. 9,974/2000. Lei n. 9.974 de 6 de junho de 2000. Retrieved from http://www.planalto.gov.br/ ccivil_03/leis/19974.htm

Brasil, Decreto No. 4.074. Lei n. de 4 de janeiro de 2002. Diário Oficial da União, Brasilia. Retrieved January 8, 2002, from http://www.planalto.gov.br/cCIVIL_03/decreto/2002/D4074.htm

Brasil, Regulation No. 9843/2004. Norma n. 9843 de 30 de abril de 2004. Retrieved from http://www. ecoagencia.com.br/documentos/norma_agrotoxicos_afins.pdf

Brasil, Law No. 12,305/2010. Lei n. 12.305, de 02 de agosto de 2010. Diário Oficial da União, Brasília, DOFC 02/08/2010. Retrieved from http://www.planalto.gov.br/ccivil_03/_ato2007-2010/2010/lei/112305.htm

Carvalho, F. P. (2017). Pesticides, environment, and food safety. Food and Energy Security, 6(2), 48-60. https://doi.org/10.1002/fes3.108

Chaves Preza, D. L., \& Da Silva Augusto, L. G. (2012). Vulnerabilidades de trabalhadores rurais frente ao uso de agrotóxicos na produção de hortaliças em região do Nordeste do Brasil. Revista Brasileira de Saúde Ocupacional, 37(125), 89-98. https://doi.org/10.1590/S0303-76572012000100012

Cirne, P. S. (2006). A destinação final das embalagens de agrotóxicos: recentes modificações. Revista do Ministério Público do RS, 47, 273-283.

Cohen, A. J., Brauer, M., Burnett, R., Anderson, H. R., Frostad, J., Estep, K., .. Forouzanfar, M. H. (2017). Estimates and 25-year trends of the global burden of disease attributable to ambient air pollution: An analysis of data from the Global Burden of Diseases Study. The Lancet, 389(10082), 1907-1918. https://doi.org/10.1016/S0140-6736(17)30505-6

Da Costa Leite, K., \& Torres, M. (2008). O uso de agrotóxicos pelos trabalhadores rurais do assentamento catingueira Baraúna-RN. Revista Verde de Agroecologia e Desenvolvimento Sustentável, 3(4), 6-28.

Dasgupta, S., Meisner, C., Wheeler, D., \& Jin, Y. (2002). Agricultural trade, development and toxic risk. World Development, 30(8), 1401-1412. https://doi.org/10.1016/S0305-750X(02)00045-1

Da Rosa, J. M., Ariolli, C., Blochtein, B., Agostinetto, L., Grutzmacher, A. D., \& Botton, M. (2018). Diagnosis of directed pollination services in apple orchards in Brazil. Revista Brasileira de Fruticultura, 40(2), 1-7. https://doi.org/10.1590/0100-29452018234

De Castro, V. L. S. S. (2009). Uso de misturas de agrotóxicos na agricultura e suas implicações toxicológicas na saúde. Journal of the Brazilian Society of Ecotoxicology, 4(1-3), 87-94. https://doi.org/10.5132/ jbse.2009.01.012

De Lima, C. A. B., Grützmacher, D. D., \& Krüger, L. R. (2009). Diagnóstico da exposição ocupacional a agrotóxicos na principal região produtora de pêssego para indústria do Brasil. Ciência Rural, 39(3), 900-903. https://doi.org/10.1590/S0103-84782008005000090 
De Souza, L. C. (2018). Análise da legislação sobre agrotóxicos no Brasil: Regulação ou desregulação do controle do uso. Revista Jurídica da Escola Superior do Ministério Público de São Paulo, 11(1), 41-74.

De Souza, J. P., Faria, H. A., \& Pereira, R. S. F. (2017). Uso de agrotóxico pelos trabalhadores rurais do município de Crisópolis-BA. Estação Científica, 7(3), 107-117. https://doi.org/10.18468/estcien.2017v7n3. p107-117

Eskenazi, B., Bradman, A., \& Castorina, R. (1999). Exposures of children to organophosphate pesticides and their potential adverse health effects. Environmetal Health Perspective, 107(3), 409-419. https://doi.org/ 10.1289/ehp.99107s3409

FAO. (2002). International Code of Conduct on the Distribution and Use of Pesticides. Retrieved from http://www.fao.org/docrep/018/a0220e/a0220e00.pdf

Farias, R. D. M., Nunes, J. L. D. S., Martins, C. R., Guerra, D. S., Zanini, C. L. D., \& Marodin, G. A. B. (2003). Produção convencional $\times$ integrada em pessegueiro cv. Marli na depressão central do Rio Grande do Sul. Revista Brasileira de Fruticultura, 25(2), 253-255. https://doi.org/10.1590/S0100-29452003000200017

Frazier, L. M. (2007). Reproductive disorders associated with pesticide exposure. Journal of Agromedicine, 12(1), 27-37. https://doi.org/10.1300/J096v12n01_04

Friedrich, K., Soares, V. E., Da Silva Augusto, L. G., Gurgel, A. M., Souza, M. M. O., Alexandre, V. P., \& Carneiro, F. F. (2018). Agrotóxicos: Mais venenos em tempos de retrocessos de direitos. Geografia em Debate., 12(2), 326-347. https://doi.org/10.22478/ufpb.1982-3878.2018v12n2.41320

Gerassi, P. V. M. (2010). Manual de destinação final de embalagens vazias de produtos fitossanitários. Retrieved from http://www.fiocruz.br/biosseguranca/Bis/manuais/residuos/Manual\%20de\%20Destinacao\% 20de\%20Residuos\%20Fitosanitarios.pdf

Huici, O., Skovgaard, M., Condarco, G., Jørs, E., \& Jensen, O. C. (2017). Management of Empty Pesticide Containers-A Study of Practices in Santa Cruz, Bolivia. Environmental Health Insights, 11, 1-7, https://doi.org/10.1177/1178630217716917

IBGE (Instituto Brasileiro de Geografia e Estatística). (2016). Produção Agrícola Municipal. Retrieved from https://cidades.ibge.gov.br

IBGE (Instituto Brasileiro de Geografia e Estatística). (2017). Levantamento Sistemático da produção Agrícola. Retrieved from https://www.ibge.gov.br/estatisticas-novoportal/economicas/agricultura-e-pecuaria/9201levantamento-sistematico-da-producao-agricola.html $?=\& \mathrm{t}=$ series-historicas

INPEV (Instituto Nacional de Procesamento de Embalagens Vazias). (2016). Relatório de Sustentabilidade 2016. Retrieved from http://inpev.org.br/relatorio-sustentabilidade/2016/pt/index.html

Konradsen, F., Van Der Hoek, W., Cole, Dc, Hutchinson, G., Daisley, H., Singh, S., \& Eddleston, M. (2003). Reducing acute poisoning in developing countries-Options for restricting the availability of pesticides. Toxicology, 192(2-3), 249-261. https://doi.org/10.1016/S0300-483X(03)00339-1

Luna, A. J., Sales, L. T., \& Silva, R. F. (2011). Agrotóxicos: Responsabilidade de todos (uma abordagem da questão dentro do paradigma do desenvolvimento sustentável). Jaboticabal: UNESP. Retrieved from http://www.segurancaetrabalho.com.br/download/agrotoxicos-responsabilidade.doc

Maluche-Barreta, C. R. D., Klauberg filho, O. A., Amarante, C. V. T. R., Genicelli, M., \& Almeida, D. (2007). Atributos microbianos e químicos do solo em sistemas de produção convencional e orgânico de maçãs no estado de Santa Catarina. Revista Brasileira de Ciência do Solo, 31(4), 655-665. https://doi.org/10.1590/ S0100-06832007000400006

Marnasidis, S., Stamatelatou, K., Verikouki, E., \& Kazantzis, K. (2018). Assessment of the generation of empty pesticide containers in agricultural areas. Journal of Environmental Management, 224, 37-48. https://doi.org/10.1016/j.jenvman.2018.07.012

Marques, M. D., Junior, S. S., \& Cataneo, P. F. (2015). Discussão da estrutura formal sobre o retorno das embalagens de agrotóxicos: Uma revisão teórica sob os aspectos legais e da consciência ambiental. Periódico Eletrônico Fórum Ambiental da Alta Paulista, 11(2), 30-56. https://doi.org/10.17271/ 1980082711220151085

Marques, M. D., Vieira, S. C., \& Junior, S. S. B. (2016). A Logística Reversa de Embalagens Vazias de Agrotóxicos junto a produtores rurais do Interior do Estado de São Paulo. Periódico Eletrônico Fórum Ambiental da Alta Paulista, 12(3), 1-13. https://doi.org/10.17271/1980082712320161408 
Mecabô, C. V. O. (2018). conhecimento da logística reversa e as responsabilidades na devolução das embalagens vazias de agrotóxicos. Revista Gestão e Sustentabilidade Ambiental, 7(1), 539-558. https://doi.org/ 10.19177/rgsa.v7e12018539-558

Mello, M. F., \& Scapini, R. (2016). Reverse logistcs of agrochemical pesticide packing and the impacts to the environment. Brazilian Journal of Operations \& Management, 13, 110-117. https://doi.org/10.14488/ BJOPM.2016.v13.n1.a13

Moreira, J. C., Jacob, J. S., \& Peres, F. (2002). Avaliação integrada do impacto do uso de agrotóxico sobre a saúde humana em uma comunidade agrícola de Nova Friburgo, RJ. Ciência e Saúde Coletiva, 7(2), 299-31110. https://doi.org/10.1590/S1413-81232002000200010

Nguyen, T. M, Le, N. T. T., Havukainen, J., \& Hannaway, D. B. (2017). Pesticide use in vegetable production: A survey of Vietnamese farmer' knowledge. Plant Protection Science, 54(2), 1-11.

Oliveira-Silva, J. J., Alves, S. R., \& Meyer, A. (2001). Influência de fatores socioeconômicos na contaminação por agrotóxicos, Brasil. Revista de Saúde Pública, 35(2), 130-135. https://doi.org/10.1590/S0034-89102001 000200005

Pegoraro, C., Maciejewski, P., Manica-Berto, R., Pegoraro, C., Oliveira, F. M., \& Silva, J. A. (2016). Percepção dos produtores à aplicação de agrotóxicos na produção de pêssego in natura na metade sul do RS. Revista da Jornada da Pós-Graduação e Pesquisa-Congrega Urcamp.

Peres, F., \& Moreira, J. C. (2007). Saúde e Ambiente em sua relação com o consumo de agrotóxicos em um polo agrícola do Estado do Rio de Janeiro, Brasil. Caderno Saúde Pública, 23(4), S612-S621. https://doi.org/ $10.1590 / \mathrm{S} 0102-311 \mathrm{X} 2007001600021$

Ribeiro, H. G., De Moura Alves, E., \& De Moura Lustosa, R. A. (2017). Importância e a caracterização da Agricultura Familiar em Dom Expedito Lopes-PI. Revista IESM, 1(1), 1-12.

Santos, C. A., \& Machado, H. C. (2015). O uso de agrotóxicos e a saúde do trabalhador rural-seus aspectos comportamentais e fisiológicos. Novos Direitos, 2(1), 114-126.

Secretaria de Estado de Desenvolvimento Regional-SDR São Joaquim. (2003). Retrieved from http://docweb. epagri.sc.gov.br/website_cepa/publicacoes/diagnostico/SAO_JOAQUIM.pdf

Serviço Brasileiro de Apoio às Micro e Pequenas Empresas-SEBRAE Nacional. (2018). Retrieved from http://www.sebrae.com.br/sites/PortalSebrae/artigos/o-cultivo-e-o-mercado-da-maca,ea7a9e665b182410Vg nVCM100000b272010aRCRD

Skevas, T., Lansink, A. O., \& Stefanou, S. E. (2013). Designing the emerging EU pesticide policy: A literature review. Journal of Life Sciences, 64(65), 95-103. https://doi.org/10.1016/j.njas.2012.09.001

Terto, H. E. B., \& Andrade, L. R. (2017). Utilização de agrotóxicos por trabalhadores rurais na microbacia do córrego das areias no município de nova Brasilândia d 'Oeste-RO. Revista Científica da UNESC, 15(1), $1-14$.

Veiga, M. M., Silva, D. M., \& Veiga, L. B. E. (2006). Análise da contaminação dos sistemas hídricos por agrotóxicos numa pequena comunidade rural do Sudeste do Brasil. Caderno Saúde Pública, 22(11), 2391-2399. https://doi.org/10.1590/S0102-311X2006001100013

Viana, L. S., Queiroz, I. F. R., \& Ribeiro, M. A. (2017). Contextualizando a realidade do uso de agrotóxicos na agricultura familiar. Extensão em Ação, 1(13), 54-68.

Vinha, M. B., De Oliveira Pinto, C. L., \& Pinto, C. M. F. (2011). Impactos do uso indiscriminado de agrotóxicos em frutas e hortaliças. Revista Brasileira de Agropecuária Sustentável, 1(1), 98-103. 


\section{Appendix A}

Identification and characterization of the pesticides most used by apple farmers in the rural areas of São Joaquim, Santa Catarina State, Brazil

\begin{tabular}{|c|c|c|c|c|c|c|c|}
\hline Commercial name & Active ingredient & $\begin{array}{l}\text { Average quantity } \\
\text { used per year } \\
\text { ( } \mathrm{L} \text { or } \mathrm{Kg} \text { ) }\end{array}$ & $\begin{array}{l}\% \text { farmers } \\
\text { interviewed that } \\
\text { use this pesticides } \\
\end{array}$ & $\begin{array}{l}\text { Recommended } \\
\text { to apple }\end{array}$ & $\begin{array}{l}\text { Toxicity } \\
\text { class* }\end{array}$ & $\begin{array}{l}\text { Environmental } \\
\text { Class*** }\end{array}$ & Agronomic category \\
\hline Abamectin & abamectin & $7.0 \mathrm{~L}$ & 1.22 & yes & III & III & Acaricide Insecticide \\
\hline Alto 100 & cyproconazole & $5.0 \mathrm{~L}$ & 1.22 & yes & III & II & Fungicide \\
\hline Altacor & clorantraniliprole & $151.5 \mathrm{Kg}$ & 2.44 & yes & III & II & Insecticide \\
\hline Antracol & propineb & $47.0 \mathrm{~L}$ & 4.88 & yes & II & IV & Fungicide \\
\hline Bravonil & chlorothalonil & $35.28 \mathrm{Kg}$ & 8.54 & yes & II & II & Fungicide \\
\hline Cabrio Top & $\begin{array}{l}\text { methyram }+ \\
\text { pyraclostrobin }\end{array}$ & $35.0 \mathrm{Kg}$ & 2.44 & yes & III - & II & Fungicide \\
\hline Captan & captan & $105.47 \mathrm{~L}$ & 52.44 & yes & I & II & Fungicide \\
\hline Cercobin & thiophanate-methyl & $14.5 \mathrm{Kg}$ & 9.75 & yes & I & II & Fungicide \\
\hline Delan & dithianone & $35.28 \mathrm{Kg}$ & 17.07 & yes & I & II & Fungicide \\
\hline Difcor & diphenoconazole & $10.0 \mathrm{~L}$ & 1.22 & yes & I & II & Fungicide \\
\hline Dithane & mancozeb & $218.06 \mathrm{Kg}$ & 78.05 & yes & I & II & Fungicide \\
\hline Flint $500 \mathrm{WG}$ & trifloxystrobin & $2.0 \mathrm{Kg}$ & 1.22 & yes & III & II & Fungicide \\
\hline Fronwside $500 \mathrm{SC}$ & fluazinam & $24.47 \mathrm{~L}$ & 8.54 & yes & II & I & Fungicide Acaricide \\
\hline Gramoxone 200 & Paraquat dichloride & $15.0 \mathrm{~L}$ & 3.66 & yes & I & II & Herbicide \\
\hline Imidan $500 \mathrm{WP}$ & fosmet & $22.6 \mathrm{Kg}$ & 31.71 & yes & I & III & Insecticide \\
\hline Isatalonil $500 \mathrm{SC}$ & chlorothalonil & $44.61 \mathrm{~L}$ & 17.07 & yes & II & II & Fungicide \\
\hline Lorsban $480 \mathrm{BR}$ & chlorpyrifos & $20.11 \mathrm{~L}$ & 14.63 & yes & I & II & Acaricide Insecticide \\
\hline Malathion & malathion & $14.0 \mathrm{~L}$ & 3.66 & yes & III & II & Insecticide \\
\hline Mancozeb & mancozeb & $50.0 \mathrm{Kg}$ & 2.44 & yes & III & II & Fungicide \\
\hline Manzate 800 & mancozeb & $142.85 \mathrm{~kg}$ & 12.19 & yes & I & II & Fungicide \\
\hline Metiltiofan & thiophanate-methyl & $1.0 \mathrm{Kg}$ & 1.22 & yes & III & III & Fungicide \\
\hline Mythos & pyrimethanil & $40.17 \mathrm{~L}$ & 35.36 & yes & III & II & Fungicide \\
\hline Nomolt 150 & teflubenzuron & $10.0 \mathrm{~L}$ & 1.21 & yes & IV & II & Insecticide \\
\hline Polyram DF & metiram & $400.0 \mathrm{Kg}$ & 2.44 & yes & III & III & Fungicide \\
\hline Previnil & chlorothalonil & $30.0 \mathrm{~L}$ & 1.22 & yes & I & II & Fungicide \\
\hline Prisma & diphenoconazole & $14.69 \mathrm{~L}$ & 18.29 & yes & I & II & Fungicide \\
\hline Pyrinex 480 EC & chlorpyrifos & 26.1 & 13.41 & yes & I & II & Insecticide \\
\hline Roundup Transorb & $\begin{array}{l}\text { Glyphosate } \\
\text { isopropylamine salt }\end{array}$ & $24.05 \mathrm{~L}$ & 3.66 & yes & II & III & Herbicide \\
\hline Sanmite EW & pyridaben & $11.0 \mathrm{~L}$ & 2.44 & yes & III & III & Acaricide Insecticide \\
\hline Score & diphenoconazole & $14.70 \mathrm{~L}$ & 57.32 & yes & I & II & Fungicide \\
\hline Sumithion $500 \mathrm{EC}$ & fenitrothion & 39.12 & 60.97 & yes & II & II & Insecticide \\
\hline Supracid & $\begin{array}{l}\text { No registration } \\
\text { in "Agrofit"2 }\end{array}$ & & 2.44 & & & & \\
\hline Suprathion $400 \mathrm{EC}$ & methidathion & $40.23 \mathrm{~L}$ & 36.58 & yes & I & II & Insecticide \\
\hline Rimon $100 \mathrm{EC}$ & novaluron & $20.0 \mathrm{~L}$ & 1.22 & yes & I & II - & Insecticide \\
\hline Trifmine & triflumizole & $12.2 \mathrm{Kg}$ & 6.10 & yes & IV & III & Fungicide \\
\hline Triona & mineral oil & $75.75 \mathrm{~L}$ & 4.88 & yes & IV & III & Insecticide \\
\hline Venturol & $\begin{array}{l}\text { No registration } \\
\text { in "Agrofit" }\end{array}$ & $50.0 \mathrm{~kg}$ & 1.22 & - & - & - & - \\
\hline
\end{tabular}

Note. ${ }^{1}$ Total number of apple farmers $=82 .{ }^{2}$ It is an information bank on agrochemicals and related products registered with the Brazilian Ministry of Agriculture. Retrieved from http://agrofit.agricultura.gov.br/ agrofit_cons/principal_agrofit_cons

* Class I extremely hazardous; Class II highly hazardous; Class III moderately hazardous; Class IV slightly hazardous. ** Class I extremely hazardous to the environment; Class II highly hazardous to the environment; Class III moderately hazardous to the environment; Class IV slightly hazardous to the environment.

\section{Copyrights}

Copyright for this article is retained by the author(s), with first publication rights granted to the journal.

This is an open-access article distributed under the terms and conditions of the Creative Commons Attribution license (http://creativecommons.org/licenses/by/4.0/). 